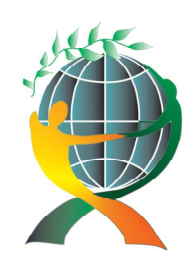

\author{
(online) $=$ ISSN $2285-3642$ \\ ISSN-L = 2285-3642 \\ Journal of Economic Development, Environment and People \\ Volume 9 , Issue 4, 2020 \\ URL: http://jedep.spiruharet.ro \\ e-mail: office_jedep@spiruharet.ro
}

\title{
Difference in Funding Decision Based on the Growth Potential of the Company in Indonesia
}

\author{
Darmawan ${ }^{1}$, Md. Edrich Molla ${ }^{2}$ \\ Faculty of Economics and Business Islam, Sunan Kalijaga State Islamic University Yogyakarta, \\ Indonesia ${ }^{11}$; Department of Business Administration Victoria University of Bangladesh ${ }^{2}$
}

\begin{abstract}
The purpose of the study, The research objective was to find out the differences in funding decisions between companies that have high growth potential and companies that have low growth potential. Research is a quantitative study. The mean difference test is preceded by Common Factor Analysis to analyze which factors in the Investment Opportunity Set can represent the growth ratio of the company so that it can be used to separate companies with high and low growth potential. Furthermore, the analysis is carried out with a regression model to determine the difference in funding decisions on the growth potential of different companies. The results showed that The consumer goods industry and mining sector sectors that have not proven to be significant are the differences in funding decisions between companies that have the potential to grow high and those with low growth potential. In other sectors, it is evident that there are significant differences in funding decisions between companies that have the potential to grow high and those with low growth potential.
\end{abstract}

Keywords: Funding; Company Growth Potential

JEL Codes: M21

How to cite: Darmawan, D. (2020). Difference in Funding Decision Based on the Growth Potential of the Company in Indonesia. Journal of Economic Development, Environment and People, 9(4). doi:http://dx.doi.org/10.26458/jedep.v9i4.678

\footnotetext{
${ }^{1}$ Coresponding author emails: darmawan@uin-suka.ac.id ; edrichmollajewel@gmail.com
} 


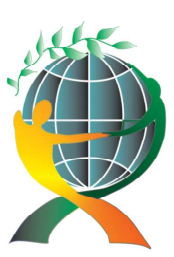

\author{
(online) $=$ ISSN $2285-3642$ \\ ISSN-L = $2285-3642$ \\ Journal of Economic Development, Environment and People \\ Volume 9 , Issue 4, 2020 \\ URL: http://jedep.spiruharet.ro \\ e-mail: office jedep@spiruharet.ro
}

\title{
1. Introduction
}

The company's growth is the hope of the company owner. All the owners of the company are essentially making investments indeed to increase the value of wealth which in this case is proxied by the value of the company. For every investor, the prospect of a company that has high growth potential provides benefits because the investment invested is expected to get a high return in the future. The company's growth opportunities can be proxied by various combinations of investment opportunities or referred to as Investment Opportunity Sets (IOS), Jiambalvo and Rajgopal (2002: 117-145).

Furthermore, Bird, Schjoedt, \& Baum (2012), and Kollmann \& Kuckertz (2010) argue that qualities of the entrepreneur such as competence and characteristic of investment are the crucial aspects that should be considered by the owner of companies. That is to say, the more capable companies demonstrate their business competency clearly in public, the more investments they get (Lakshmi Balachandra, 2017). Besides, Kaplan and Strömberg (2001) explain that a company's practices in pre-investments screening, structuring investments, post-investments monitoring, and advising is highly recommended to consider before taking action (Paul A. Gompers, 2019). Such investment growth certainly must be supported by good funding sources. The Pecking order theory explains why companies will determine the most preferred source hierarchy. Also, the financial company's condition determines the capital structure of its. This is because, the merits of company's capital structure would have a direct impact on the financial position of the company (Ida Ayu Kayika Apsari, 2019). Suad Husnan (2010: 324-325) states Pecking Order Theory as follows, The theory is addressed by Myers and Majluf (1984) and Myers (1984). This theory tries to explain the funding decisions taken by the company. In summary, the theory states that (Brealey and Myers, 1991): Companies like internal financing (funding from the results of company operations).

In accordance with this theory, there is no target of debt to equity ratio, because there are two types of own capital, namely internal and external. Own capital comes from within the company is preferred over its own capital from outside the company. Pecking order theory explains why profitable companies borrow in small amounts. This is not because they require little external financing. Less profitable companies will tend to have larger debt for two reasons, (i) insufficient funds, and (ii) debt is the preferred external source. The selection of this funding sequence shows that this funding is based on the level of cost of funds from these sources which are also related to the level of risk of an investment (Cesar Armando Mendoza Palma, 2018).

Various studies on the Investment Opportunity Set (IOS) have been carried out both at home and abroad. Several studies have been conducted but there are differences in the findings of Fijrijanti \& Hartono (2000: 851-877) finding that companies that grow have lower funding policies than companies that do not grow. On the other hand, Iswayuni \& Suryanto (2002: 120-148) state that there is no significant difference between growing companies and companies that do not grow in terms of making funding policies. The results of this study indicate that there is conflict so that it indicates that further research needs to be done on the analysis of differences in funding policies for potentially high-growth companies and companies with the potential to grow low. Whereas 
Herdinata's research $(2009,237-248)$ found differences in funding policies between companies that have high growth potential and companies that have low growth potential, where

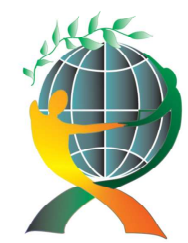

\author{
(online) = ISSN $2285-3642$ \\ ISSN-L = $2285-3642$ \\ Journal of Economic Development, Environment and People \\ Volume 9 , Issue 4, 2020 \\ URL: http://jedep.spiruharet.ro \\ e-mail: office_jedep@spiruharet.ro
}

the level of corporate debt that has the potential to grow is higher than companies that have low growth potential. This means that companies with high growth potential have more debt than companies with the potential to grow low because companies with high potential growth are thought to have high investment opportunities so that high funding is needed which is not enough if it is only funded from the internal company.

These studies show a contradiction so that it is still necessary to re-examine the analysis of differences in funding decisions between companies that have high growth potential and companies that have low growth potential.

\title{
2. Literature Review 2.1 Pecking order theory
}

Capital structure theory has evolved over time. Capital structure is a comparison or balance of long-term debt to own capital. According to J. Fred Weston and Thomas E Copeland (1996) said that the capital structure is permanent financing consisting of long-term debt, preferred shares, and shareholder capital. Lisana B. Martinez, Valeria Scherger, and M. Belén Guercio argue capital structure of such companies is an accumulation of companies conditions, which combines financing decisions of entrepreneurs, credit rationing of providers of funds, and market conditions, which are all conditioned by the phenomenon of asymmetric information (Lisana B. Martinez, 2018) The development of capital structure theory starts from the emergence of The Net Income Approach, The Net Operating Income Approach, and the Traditional Approach.

The weakness of previous theories was corrected by the emergence of the Trade Off Theory and the Pecking Order Theory. The Trade off theory explains the relationship between tax, the risk of bankruptcy, and the use of debt caused by capital structure decisions taken by the company (Brealey and Myers, 1991). Pecking order theory assumes that the company aims to maximize the welfare of shareholders. The company seeks to issue the first securities from the internal, retained earnings, then the last low-risk and equity debt (Myers, 1984). Pecking order theory predicts that external debt funding is based on internal funding deficits. The pecking order theory model focuses on corporate manager motivation, not on the principles of capital market valuation.

Pecking order theory reflects the problems created by asymmetric information. The rationale is based on the following explanation (Meyers, 1984): Managers know more about companies than outside investors, but they are reluctant to issue shares when they believe their shares are undervalued. Investors understand that managers know more and they try to publish according to the right time. Managers interpret the decision to issue equity as bad news, and companies can issue equity only at a discounted price. Companies that work based on the philosophy of pecking order theory and require external equity may not take advantage of good investment opportunities, because stocks cannot be sold at "fair price". According to Klaus Dommes, Michael Schmitt, and Elmar Steurer such companies can use pecking order theory is an 
alternative explanation for a corporate financing decision. That is to say, this theory can analyze such phenomenon of price declines when the capital increases (Klaus Dommes, 2019).

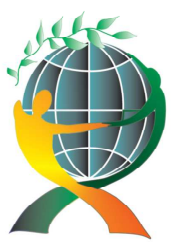

\author{
(online) = ISSN $2285-3642$ \\ ISSN-L = $2285-3642$ \\ Journal of Economic Development, Environment and People \\ Volume 9 , Issue 4, 2020 \\ URL: http://jedep.spiruharet.ro \\ e-mail: office jedep@spiruharet.ro
}

According to Myers (1977) companies prefer the use of funding from internal capital, namely funds originating from cash flow, retained earnings, and depreciation. The order of the use of funding sources by referring to pecking order theory is the internal fund, debt, and equity. Meanwhile, according to the research conducted by Ida Ayu Kayika A and Ni Ketut R delineates that companies that using internal funds are mostly the companies that already matured. Nevertheless, at the growth of small companies, they tend to maximize both capital sources (internal and external) to establish their financial condition. Debt and corporate capital are the two choices that are frequently used by most of the growth or small companies (Ida Ayu Kayika Apsari, 2019).

\title{
2.2 Corporate Growth Through IOS Proxy Approach
}

Smith and Watts (1992: 263-292) explain that IOS is a component of corporate value that comes from the choice to make investments in the future. Research by Kallapur and Trombley (1999: 3-5) states that IOS companies influence the way companies are valued by managers, owners, investors, and creditors. While Kole and Lehn (1991) explain that the value of IOS depends on expenditures by future management and is now expected to provide returns greater than the cost of capital. Even related to stock price movements, Khanna and Palepu (1999) state that IOS is the dominant factor. From the above definition, it can be interpreted that the IOS contains two terms. First, IOS is an investment decision by the company to provide positive growth, so that IOS is considered a growth prospect. Second, IOS is the company's ability to determine the type of investment to be made. For companies that are not able to choose the right investment, expenditure will be higher than the value of the opportunity lost. Therefore, it can be concluded that IOS is the relationship between current expenditure and future values / returns/prospects as a result of investment decisions to generate shareholder value.

Such level of dividend growth and risk of companies can be known at the same time which expected by the investors due to the Investment Opportunity Settlement (IOS). Besides, there is a prominent factor that can be illustrated such companies condition excellently, that is the size of the companies themselves. The bigger size of companies, the more increased investment options. Thus, it is easier for companies to compete and control the market (Permata Sari, 2019). In addition, to guarantee investment in such sectors, investors need guarantees of long-term investment sustainability (Malik, 2017).

Company value is a combination of the asset in place and future investment options. The future investment option is not only indicated by the existence of projects supported by research and development activities, but also the company's ability to exploit opportunities to take advantage more than other companies in an industry group. The company's ability cannot be measured with certainty or cannot be observed. Therefore, a proxy for the growth of the company was developed, hereinafter referred to as the IOS Proxy. This study uses five IOS proxies according to those used by Subekti \& Kusuma (2000: 356-370); AlNajjar \& Ahmed (2001: 72-99), the book value of plant, property, and equipment to asset ratio (PPE / BVA), MVA / BVA market to book of asset ratio, 
market to the book of equity ratio (MVE / BE ), price-earnings ratio (PER), and capital book of asset ratio (CAP / BVA).

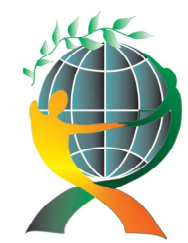

\author{
(online) = ISSN $2285-3642$ \\ ISSN-L = $2285-3642$ \\ Journal of Economic Development, Environment and People \\ Volume 9 , Issue 4, 2020 \\ URL: http://jedep.spiruharet.ro \\ e-mail: office_jedep@spiruharet.ro
}

In measuring Investment Opportunity Set Kallapur and Trombley (2001) classify three measurement methods:

a. Price-based Investment Opportunity Set measurement

This method states that the company's growth prospects are partly expressed in prices and the company's growth prospects are partially expressed in stock prices and growing companies will have a relatively high market value for assets in place compared to companies that do not grow. The ratio that has been used in several studies related to market proxies is the Book value of plant, property, and equipment to asset ratio (PPE / BVA), the PPE / BVA ratio is used with the PPE / BVA rationale that the company's growth prospects are reflected in the number of assets still owned by the company. Market to Book Value Assets (MVA / BVA), this ratio describes the combination of assets in place with investment opportunities. Therefore, the higher the MVA / BVA ratio, the higher the investment opportunity the company has in relation to assets in place. Market to Book Value Equity (MVE / BVE), this ratio is used with the rationale that MVE / BVE reflects that the market assesses the return on the company's investment in the future will be greater than the expected return on its equity.

b. Investment-based Investment Opportunity Set Measurement

The IOS-based investment proxy is a proxy that believes in the idea that a high level of investment activity is positively related to the IOS value of a company. The ratio to be used in this study is the Capital Additions to Book Assets Value (CAP / BVA), this ratio is used with the premise that the greater the capital increase made by the company, the higher the level of investment made by the company.

c. Variants-based Investment Opportunity Set Measurement

This method reveals that an option will be more valuable if it uses size variability to estimate the size of the growing options, such as the variability of returns underlying the increase in assets. Research of Permata Sari and Wiwik Supratiwi delineated that companies that have the size variability that is increasingly seen from the total assets will be more likely to have good business growth (Permata Sari, 2019). This is in accordance through the report of Global Business Guide Indonesia (GBGI) which reported that the better business growth of such companies the more interest investors invests their fund to the companies. Additionally, GBGI also indicates that with increasing urbanization to cities, demand for consumption will also increase, and in line with investment in the consumer goods industry on the stock market will also rise (Global Business Guide Indonesia, 2016).

The valuation ratio provides information on how much the community values the company so that people are interested in buying shares at a price higher than the value of the book. We use this ratio in this study to understand how the community, whether considering a share price that is higher than the price of its book, is one indication of the good growth of the company? This study used the PER ratio. Price-earnings ratio (PER), this ratio is to measure how much the comparison between the company's stock price and the profits obtained by the shareholders. 
The study itself decided that it would only use book value of plant, property, and equipment to asset ratio (MVE / BVA), MVA / BVA market to book ratio, an asset to equity ratio (MVE / BE),

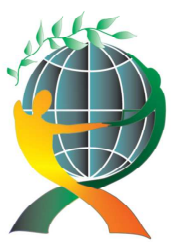

\author{
(online) = ISSN $2285-3642$ \\ ISSN-L = $2285-3642$ \\ Journal of Economic Development, Environment and People \\ Volume 9 , Issue 4, 2020 \\ URL: http://jedep.spiruharet.ro \\ e-mail: office_jedep@spiruharet.ro
}

price-earnings ratio (PER), and the capital book of asset ratio (CAP / BVA) in an effort to understand IOS.

\title{
2.3 Funding Decisions
}

Funding is an activity of allocating funds to fund investment activities. Basically, funding can be classified into two namely internal financings through retained earnings and external financing through the issuance of new debt and shares. (Donalson, 1961). Most companies tend to determine the source selection, and usually, they tend to choose the internal financing sources, if the equity of its is not sufficient they would be used the external sources. Meeting the needs of funds from external funding sources means increasing the amount of debt which would simultaneously create an obligation for the company to pay in the future. (Nur Triani, 2019).

Funding decisions are made by considering a combination of economical funding sources to meet the company's investment needs by calculating the capital cost of the investment (cut-off rate of investment) (Sudarma, 1998). In each alternative funding contains a cost called the cost of capital. Capital costs are the real costs that must be incurred by the company to obtain funds originating from debt, preferred shares, ordinary shares, and retained earnings to fund an investment or operating company. Capital costs are the main consideration of each manager to decide which funding source is best for the company. In addition, Achmad and Amanah (2014) argue that a funding decision is a decision on the shape and composition of funding that will be used by the company (Nur Triani, 2019).

Moreover, Rafika and Santoso (2018) found that firm value can be impacted by funding decisions. The debt to equity ratio (DER) is used as an indicator of the funding decisions in this study, that is the ratio between the total debt of the company, either current debt or long-term debt with its own capital (equity). So, when the amount of DER increases then PBV also going to be increasing because the amount of debt can help management in the company operating. Finally, investors think that increasing debt can increase companies' performance like a Banks' mind (Nur Triani, 2019).

Factors that need to be considered in determining the company's financial resources according to Weston and Brigham (1994) are about the analysis of capital budgeting decisions concerning the requirements for the expected return on equity. But in general, companies finance their capital budget from long-term debt and preferred stock. The funding decision in this study was measured by the Debt to Equity ratio (DER) because DER reflects the proportion between total debt (total debt) and total shareholder's equity (total equity). Total debt is total liabilities (both shortterm and long-term debt); while the total shareholders' equity is the total equity (total paid-up capital and retained earnings) owned by the company.

Hypothesis: There are differences in funding policies between potentially high-growth companies and companies that have low growth potential. 


\title{
3. Methodology
}

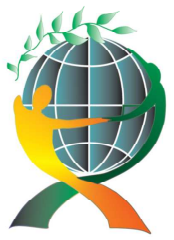

\author{
(online) $=$ ISSN $2285-3642$ \\ ISSN-L = 2285 - 3642 \\ Journal of Economic Development, Environment and People \\ Volume 9 , Issue 4, 2020 \\ URL: http://jedep.spiruharet.ro \\ e-mail: office jedep@spiruharet.ro
}

Research is a quantitative study. The average difference test is preceded by Common Factor Analysis to analyze which factors in the Investment Opportunity Set (IOS) can represent the company's growth ratio so that it can be used to separate companies with high and low growth potential. Furthermore, the analysis is done with a regression model to find out if there are indeed differences in funding decisions on the potential for growth of different companies.

The population in this study are all public companies listed on the Indonesia Stock Exchange. The sample in this study were public companies listed on the Indonesia Stock Exchange which were selected by purposive sampling method, namely samples were selected based on the suitability of sample characteristics according to the sample selection criteria determined as follows: The company was listed on the IDX for five years, 2013 to 2017; The company is not a financial institution, banking, insurance, or government company with reasons to anticipate the existence of certain regulatory influences that are characters that can affect variables in research; The company publishes financial statements during the full study period; The company has no negative profits or suffers losses in the study period.

Based on these criteria, the number of companies studied is 196 companies listed on the IDX. With the distribution of the largest head office in Jakarta as many as 149 companies, the rest spread in various cities in Indonesia. The data used in this study are secondary data which includes financial statement data, closing prices of shares, the number of outstanding shares obtained from the Indonesian Capital Market Directory (ICMD).

Measurement of research variables is addressed in the following table:

Table 1 Measurement of Research Variables

\begin{tabular}{|c|c|}
\hline Variables & Measurement \\
\hline $\begin{array}{l}\text { Investment } \\
\text { Opportunity } \\
\text { Set (IOS) }\end{array}$ & $\begin{array}{l}\text { 1. } \frac{P P E}{B V A}=\frac{\text { book value of fixed assets }}{\text { book value of total assets }} \\
\text { 2. } \frac{M V A}{B V A}= \\
(\text { total assets }- \text { total equity }+(\text { total outstanding shares } \times \text { stock closing price }))\end{array}$ \\
\hline & $\begin{array}{l}\text { 3. } \frac{M V E}{B V E}=\frac{\text { (number of outstanding shares } \times \text { stock closing price })}{\text { total equity }} \\
\text { 4. } P E R=\frac{\text { stock closing price }}{\text { earnings per share }} \\
\text { 5. } \\
\frac{C A P}{B V A}=\frac{\text { additional share capital in } 1 \text { year }}{\text { total assets }}\end{array}$ \\
\hline $\begin{array}{l}\text { Funding } \\
\text { Decision }\end{array}$ & $D E R=\frac{\text { Total debt }}{\text { total equity }}$ \\
\hline
\end{tabular}

Source: Data processing 


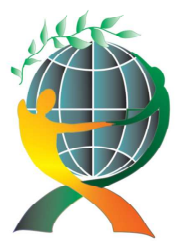

\author{
(online) $=$ ISSN $2285-3642$ \\ ISSN-L = $2285-3642$ \\ Journal of Economic Development, Environment and People \\ Volume 9 , Issue 4, 2020 \\ URL: http://jedep.spiruharet.ro \\ e-mail: office jedep@spiruharet.ro
}

\title{
4. Results
}

\subsection{Grouping Based on Company Growth Potential}

To analyze funding decisions, Common Factor Analysis will be carried out first. Based on $\mathrm{t}$ Common Factor Analysis, it can be seen that the price-based investment opportunity set measurement (PPE / BVA and MVA / BVA) shows the ability to explain the company's growth potential rather than other measurement methods. This method states that the company's growth prospects are partly expressed in prices and the company's growth prospects are partially expressed in stock prices and growing companies will have a relatively high market value for assets in place compared to companies that do not grow.

\subsection{Descriptive Statistics of Funding Decisions}

For the description of statistical data based on the potential for growth which is proxied by Book value of plant, property, and equipment to asset ratio (PPE / BVA), we can see the funding decision as follows: the results of the descriptive analysis based on the Book value of plant growth proxy, property, and equipment to asset ratio (PPE / BVA) for the variables used in this study. The data in this table consists of funding decision variables (DER). In companies with the potential to grow high in DER, an average of 1.79 is obtained, meaning that companies with high growth potential have debts that are far greater than their capital, whereas for companies with the potential to grow low, the average DER is 0.72 , meaning in companies that do not grow, they have debt that is smaller than the capital they have in the funding structure.

For a description of statistical data based on potential growth, we can see the funding decision book of assets ratio (MVA / BVA) as follows: the results of the descriptive analysis based on the Market to book of asset ratio (MVA / BVA) growth proxy for the variables used in this study. The data in this table consists of funding decision variables (DER). For companies with high DER potential, 1.88 means that the potential for high-growth companies has debts that are far greater than their capital, whereas, for companies with the potential to grow low, the average DER is 0.62 , meaning that in companies that do not grow, they have debt that is smaller than the capital they have in the funding structure.

\subsection{Testing of Hypotheses}

Testing the hypothesis to find out whether there are differences in funding policies between potentially high-growth companies and companies that have low growth potential. First, it will be tested with a Book value of plant, property, and equipment to asset ratio (PPE / BVA) database. Test results are obtained as follows: 


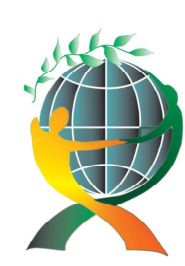

$$
\begin{gathered}
\text { (online) }=\text { ISSN } 2285-3642 \\
\text { ISSN-L }=2285-3642
\end{gathered}
$$

Journal of Economic Development, Environment and People

Volume 9 , Issue 4, 2020

URL: http://jedep.spiruharet.ro

e-mail: office_jedep@spiruharet.ro

\begin{tabular}{|c|c|c|c|c|c|}
\hline \multirow[b]{2}{*}{ Variable } & \multirow[b]{2}{*}{ The type of company } & \multirow[b]{2}{*}{$\mathrm{N}$} & \multicolumn{3}{|c|}{ Different Mean Test } \\
\hline & & & Mean & $\mathrm{t}$ & Sign \\
\hline \multirow{2}{*}{ DER } & $\begin{array}{lll}\text { Companies } & \text { Potential } & \text { to } \\
\text { Grow High } & & \end{array}$ & 490 & 1.79 & \multirow[t]{2}{*}{1.602} & \multirow[t]{2}{*}{0.11} \\
\hline & $\begin{array}{l}\text { Companies } \quad \text { Potentially } \\
\text { Grow Low }\end{array}$ & 490 & 0.72 & & \\
\hline
\end{tabular}

Table 2 Mean Difference Tests on Funding Decisions (PPE / BVA database)

Source: data processing

Both will be tested with a Market to book of asset ratio (MVA / BVA) database. Test results are obtained as follows:

Table 3 Mean Difference Test on Funding Decisions (MVA / BVA database)

\begin{tabular}{|c|l|c|c|c|c|}
\hline \multirow{2}{*}{ Variable } & \multicolumn{1}{|c|}{$\begin{array}{c}\text { The type of } \\
\text { company }\end{array}$} & $\mathrm{N}$ & Mean & $\mathrm{t}$ & $\begin{array}{l}\text { Sign } \\
\text { (2 tailed) }\end{array}$ \\
\hline \multirow{3}{*}{ DER } & $\begin{array}{l}\text { Companies Potential to } \\
\text { Grow High }\end{array}$ & 490 & 1.88 & 1.881 & 0.06 \\
& $\begin{array}{l}\text { Companies Potentially } \\
\text { Grow Low }\end{array}$ & 490 & 0.62 & & \\
\hline
\end{tabular}

Source: data processing

The results of testing this hypothesis indicate that the funding decision with a PPE / BVA database has different averages for companies that have the potential to grow DER average height of 1.79 while those that have the potential to grow low are 0.7 but the sig value is $0.11>0.05$ means that the differences in funding decisions between companies that have the potential to grow high and low are not significantly different. While the results of testing the next hypothesis show that funding decisions with the MVA / BVA database have different averages for companies that have the potential to grow the average DER height of 1.88 while those that have the potential to grow low are 0.62 but the sig value is $0.06>0.05$ means that the difference in funding decisions between companies that have the potential to grow high and low is not significantly different.

In testing the hypothesis it was found that differences in funding policies between companies that have the potential to grow high and low with proxies by PPE / BVA did not show a significant difference even though the DER average in companies with a high potential of growth was 1.79 and grew low 0.7. Because this data still includes all samples, it will be tested if it is the sector. 


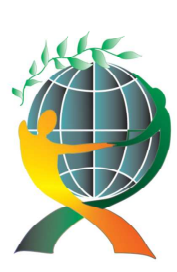

$$
\begin{gathered}
\text { (online) }=\text { ISSN } 2285-3642 \\
\text { ISSN-L }=2285-3642
\end{gathered}
$$

Journal of Economic Development, Environment and People Volume 9 , Issue 4, 2020

URL: http://jedep.spiruharet.ro e-mail: office_jedep@spiruharet.ro

\begin{tabular}{|c|c|c|c|c|c|c|}
\hline \multirow{2}{*}{ Sector } & \multirow[b]{2}{*}{ Variable } & \multirow[b]{2}{*}{ The type of company } & & \multicolumn{3}{|c|}{ Different Mean Test } \\
\hline & & & & ean $M$ & $\mathrm{t}$ & $\begin{array}{l}\text { Sign } \\
\text { (2) }\end{array}$ \\
\hline \multirow{2}{*}{$\begin{array}{l}\text { Services \& } \\
\text { Investment }\end{array}$} & \multirow{16}{*}{ DER } & $\begin{array}{l}\text { Companies Potential to } \\
\text { Grow High }\end{array}$ & 0 & 1.72 & \multirow[t]{2}{*}{4.145} & \multirow[t]{2}{*}{0.000} \\
\hline & & $\begin{array}{l}\text { Companies } \quad \text { Potentially } \\
\text { Grow Low }\end{array}$ & 0 & 0.59 & & \\
\hline \multirow{2}{*}{$\begin{array}{l}\text { Consumer } \\
\text { Goods } \\
\text { Industry }\end{array}$} & & $\begin{array}{l}\text { Companies Potential to } \\
\text { Grow High }\end{array}$ & 5 & 2.24 & 0.352 & 0.726 \\
\hline & & $\begin{array}{l}\text { Companies Potentially } \\
\text { Grow Low }\end{array}$ & 5 & 0.59 & & \\
\hline \multirow{2}{*}{ Mining } & & $\begin{array}{l}\text { Companies Potential to } \\
\text { Grow High }\end{array}$ & 5 & 1.18 & \multirow[t]{2}{*}{0.367} & \multirow[t]{2}{*}{0.714} \\
\hline & & $\begin{array}{l}\text { Companies Potentially } \\
\text { Grow Low }\end{array}$ & 5 & 1.09 & & \\
\hline \multirow[t]{2}{*}{ Trading } & & $\begin{array}{l}\text { Companies Potential to } \\
\text { Grow High }\end{array}$ & 2 & 0.35 & \multirow[t]{2}{*}{15.296} & \multirow[t]{2}{*}{0.000} \\
\hline & & $\begin{array}{l}\text { Companies } \quad \text { Potentially } \\
\text { Grow Low }\end{array}$ & 2 & 0.10 & & \\
\hline \multirow[t]{2}{*}{ Industry } & & $\begin{array}{l}\text { Companies Potential to } \\
\text { Grow High }\end{array}$ & 12 & 0.58 & \multirow[t]{2}{*}{22.762} & \multirow[t]{2}{*}{0.000} \\
\hline & & $\begin{array}{l}\text { Companies } \quad \text { Potentially } \\
\text { Grow Low }\end{array}$ & 12 & 0.23 & & \\
\hline \multirow[t]{2}{*}{ Property } & & $\begin{array}{l}\text { Companies Potential to } \\
\text { Grow High }\end{array}$ & 2 & 0.15 & \multirow[t]{2}{*}{7.019} & \multirow[t]{2}{*}{0.000} \\
\hline & & $\begin{array}{l}\text { Companies Potentially } \\
\text { Grow Low }\end{array}$ & 2 & 0.01 & & \\
\hline \multirow[t]{2}{*}{ Infrastructure } & & $\begin{array}{l}\text { Companies Potential to } \\
\text { Grow High }\end{array}$ & 2 & 0.68 & \multirow[t]{2}{*}{17.933} & \multirow[t]{2}{*}{0.000} \\
\hline & & $\begin{array}{l}\text { Companies Potentially } \\
\text { Grow Low }\end{array}$ & 2 & 0.16 & & \\
\hline \multirow[t]{2}{*}{ Agriculture } & & $\begin{array}{l}\text { Companies Potential to } \\
\text { Grow High }\end{array}$ & 0 & 0.45 & \multirow[t]{2}{*}{7.241} & \multirow[t]{2}{*}{0.000} \\
\hline & & $\begin{array}{l}\text { Companies Potentially } \\
\text { Grow Low }\end{array}$ & 0 & 0.31 & & \\
\hline
\end{tabular}

Table 4 Mean Difference Test on Funding Decisions (PPE / BVA database) by Sector

Source: data processing 


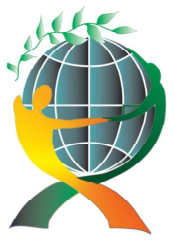

\author{
(online) $=$ ISSN $2285-3642$ \\ ISSN-L = $2285-3642$ \\ Journal of Economic Development, Environment and People \\ Volume 9 , Issue 4, 2020
}

URL: http://jedep.spiruharet.ro

e-mail: office jedep@spiruharet.ro

The results of this sectoral testing show that in the Consumer and Mining Goods Industry sector, although there are differences in funding decisions, they are proven to be insignificant so the hypothesis is rejected. While in other sectors, significant differences in funding decisions have been proven based on the company's growth potential. Henceforth the company's growth potential will be explained by PPE / BVA, or it means that the company's growth potential can be seen primarily by the ratio of the book value of equipment and machinery to the book value of its assets.

The results of the analysis of the effect of PPE / BVA on DER in the sectors that are significantly different between the high and low potential growth as follows:

Table 5 Models and $R^{2}$ between DER and PPE / BVA based on the Sector

\begin{tabular}{|c|c|c|c|c|}
\hline Sector & Var & $\begin{array}{l}\text { The type of } \\
\text { company }\end{array}$ & Model & $\mathrm{R}^{2}$ \\
\hline \multirow{2}{*}{$\begin{array}{l}\text { Services } \\
\text { \& Investment }\end{array}$} & \multirow{12}{*}{ DER } & Grow High & $\mathrm{DER}=1.235+0.877 \mathrm{PPE} / \mathrm{BVA}$ & 0.38 \\
\hline & & Grow Low & $\mathrm{DER}=1.124+2.663 \mathrm{PPE} / \mathrm{BVA}$ & 0.87 \\
\hline \multirow[t]{2}{*}{ Trading } & & Grow High & DER $=-4.072+20.614 \mathrm{PPE} / \mathrm{BVA}$ & 0.69 \\
\hline & & Grow Low & DER $=-0.056+5.041 P P E / B V A$ & 0.27 \\
\hline \multirow[t]{2}{*}{ Industry } & & Grow High & DER $=-17.496+35.032 \mathrm{PPE} / \mathrm{BVA}$ & 0.25 \\
\hline & & Grow Low & DER $=-11.230+39.900 P P E / B V A$ & 0.05 \\
\hline \multirow[t]{2}{*}{ Property } & & Grow High & $\mathrm{DER}=0.896+1.774 \mathrm{PPE} / \mathrm{BVA}$ & 0.62 \\
\hline & & Grow Low & DER $=0.103+15.501 \mathrm{PPE} / \mathrm{BVA}$ & 0.96 \\
\hline \multirow{2}{*}{ cture ${ }^{\text {Infrastru }}$} & & Grow High & DER $=-19.643+35.348 P P E / B V A$ & 0.57 \\
\hline & & Grow Low & DER $=-0.098+3.313 P P E / B V A$ & 0.53 \\
\hline \multirow{2}{*}{ ure } & & Grow High & DER $=-40.060+101.630 P P E / B V A$ & 0.76 \\
\hline & & Grow Low & DER $=-6.901+23.735 P P E / B V A$ & 0.59 \\
\hline
\end{tabular}

Source: data processing

From these results, we can see that the magnitude of the effect of PPE / BVA on DERs varies. In the Services and investment sector, the property of the influence of PPE / BVA on DER in companies with high growth potential is lower than for companies that have low growth potential. Whereas in the Trade, Industry, Infrastructure, and Agriculture sectors the magnitude of the effect of PPE / BVA on DER in companies with a high potential to grow is higher than that of companies that have low growth potential.

\title{
5. Conclusion and Discussion
}

Based on this analysis there is something interesting in the consumer goods industry sector and the mining sector which has not proven to be a significant difference in funding decisions between companies that have the potential to grow high and those with low growth potential. The same results were found in Malaysia, Nurul Shahnaz Mahdzan, et al (2016, 250-262). 


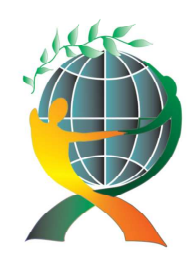

\author{
(online) $=$ ISSN $2285-3642$ \\ ISSN-L = $2285-3642$ \\ Journal of Economic Development, Environment and People \\ Volume 9 , Issue 4, 2020 \\ URL: http://jedep.spiruharet.ro \\ e-mail: office jedep@spiruharet.ro
}

There are several possibilities why the consumption goods industry sector and the mining sector have not proven to be significant differences in funding decisions between companies that have the potential to grow high and those with low growth potential. If we look at the characteristics of investment decisions, the consumer goods industry sector tends to be independent and defensive. Martin Gunawan (2017, 161-172) said that the industrial sector of consumer goods such as food and beverages, pharmaceuticals, cosmetics, and household needs, household appliances, and cigarettes dominate the stock market, indicating that every issuer is engaged in the industry because it is profitable, has high stock value and a sector that is much in demand by business owners to set up businesses and investors to invest their capital. If we look at its growth, it continues to increase due to the growth of outlets that follow housing growth.

Rudy Chandra (2010, 101-113) states that the Consumer Goods Industry has the highest institutional investor ownership because of this type of industry. has a relatively high level of product sales and growth. According to Harianto and Sudomo (1998), this industry is classified as an industry that is not much affected by changes in economic conditions (defensive industry). This means that this sector of stocks which generally grows its income on average or below average but is not very sensitive or very little influenced by business conditions. The consumer goods industry consists of several sub-industries such as the food and beverage industry, cigarettes, pharmaceuticals, cosmetics, and household goods, as well as household appliances.

Supported by GBGI's statement that has witnessed changes in lifestyle and consumption patterns in line with the rising urbanization trend. By 2030, it is estimated that $71 \%$ of the total Indonesian population will live in urban areas compared with about $55-57 \%$ at present. Consequently, this group who is categorized as middle-income people is growing in size to become the new backbone of the consumer market in Indonesia. (Global Business Guide Indonesia, 2016) This indicates that with increasing urbanization to cities, demand for consumption will also increase, and in line with investment in the consumer goods industry on the stock market will also rise.

The same thing in the mining sector, we see the characteristics of investment decisions in this sector are oil and gas, metals, and coal, which tend to be independent of the global economic conditions. This will result in funding decisions for this sector not based on general functions. This can be seen on the basis of the stand-alone mining sector in deciding its investment policy. The investment tends to be due to the discovery of new mining sites that are considered valuable. Not following consideration of market demand. Although in mining conflicts often occur with the community, Eriks proposes the need for a change in the laws and regulations in the mineral and coal sector which needs to be regulated more comprehensively so that the presence of legal alignments with indigenous peoples by utilizing the concept of legal pluralism is understood as a situation where the social arena is not only filled by state law but also in the meet with a variety of normative systems that can cause harmony as well as tension. (Eriks, 2018).

Yusuf Fatoni et al $(2013,1-11)$, stated that the mining industry is an industrial sub-sector that has very complex risks. The risks faced by these two industrial sub-sectors are very high and vary such as physical risk, market risk related to changes in domestic and global selling prices, and financial risks that are certain to occur if it turns out that the mining yields are considered economical while exploration and exploitation carried out previously has been very expensive. 


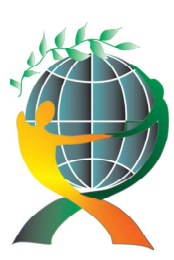

\author{
(online) $=$ ISSN $2285-3642$ \\ ISSN-L = $2285-3642$ \\ Journal of Economic Development, Environment and People \\ Volume 9 , Issue 4, 2020 \\ URL: http://jedep.spiruharet.ro \\ e-mail: office jedep@spiruharet.ro
}

Aditionally, the mining industry sector is also very affected by global economic conditions. So we see extreme angles opposite to the previous sector. Because of its highly speculative nature, investment decisions and funding do not follow a certain pattern.

Companies that have a high level of business risk, such as the mining sector, tend to reduce or even avoid using debt in funding (external funding). This is because if the higher the business risk, the possibility of financial difficulties faced by the company will also be higher. The trade-off theory explains that the higher the likelihood of financial distress, the company will bear a high cost of bankruptcy (Umar Farooq and others 2012, 96-108). Conversely, the lower the level of business risk, the possibility of financial difficulties faced by the company is also lower, so the company will be easier to use more debt. This is because companies that have a low level of business risk tend to have relatively stable earnings. A stable earnings level will affect the interest of creditors to provide larger loans.

Also, to guarantee investment in the mining sector, investors need guarantees of long-term investment sustainability. This is because the sector uses capital-intensive investment and is generally in remote areas. Indonesian Mining Institute (IMI) Deputy Chairperson, Hendra Sinadia said that the mining industry is known to have unique and different characteristics compared to other industries. According to him, the mining industry is generally a long-term investment and capital intensive. Mineral deposits are also generally located in remote areas and lack of infrastructure, making it very high risk from various aspects. Hendra said "with the technical, geological, market, fiscal, policy and environmental aspects, mining investors generally want specific regulatory regimes so that long-term investment is guaranteed," Hendra explained in his statement. (Malik, 2017).

The consumer goods industry and mining sector sectors that have not proven to be significant are the differences in funding decisions between companies that have the potential to grow high and those with low growth potential. In other sectors, it is evident that there are significant differences in funding decisions between companies that have the potential to grow high and those with low growth potential. Further research can be done to answer why the consumption sector and the mining sector have not proven significant differences in funding decisions between companies that have a high potential to grow and companies that have low growth potential?

\title{
References:
}

AlNajjar \& Ahmed, R. B. (2001). Empirical Validation of a General Model of Growth Opportunities. Journal of Managerial Finance, Vol. 27, No.3, 72-99.

Brealey, R. A. \& Myers, S. C. (1991). Principles of Corporate Finance, 4th edition. McGraw Hill Inc.

Cesar Armando Mendoza Palma, A. V. (2018). A House: A Small Company . International Journal of Physical Sciences and Engineering , 26-34.

Christian Herdinata. (2009). Kebijakan Pendanaan Dan Dividen Dengan Pendekatan Investment Opportunity Set. Jurnal Keuangan dan Perbankan, Vol. 13, No.2 Mei 2009, 237 - 248. 


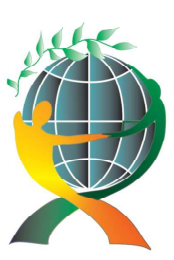

\author{
(online) $=$ ISSN $2285-3642$ \\ ISSN-L = $2285-3642$ \\ Journal of Economic Development, Environment and People \\ Volume 9 , Issue 4, 2020 \\ URL: http://jedep.spiruharet.ro \\ e-mail: office_jedep@spiruharet.ro
}

Donaldson, G. (1961). Corporate Debt Capacity: A Study of Corporate Debt Policy and Determination of Corporate Debt Capacity. Boston: Division of Research, Harvard Graduate School of Business Administration.

Eriks. (2018). Perkembangan Hukum Politik Pertambangan Mineral dan Batubara dan Implikasinya pada Hukum Adat. Yuridis, 114-115.

Fijrijanti, T. \& Hartono, J. (2000). Analisis Korelasi Pokok IOS dengan Realisasi Pertumbuhan Perusahaan, Kebijakan Pendanaan dan Dividen. Makalah Simposium Nasional Akuntansi III, 851877.

Global Business Guide Indonesia. (2016). Global Business Guide Indonesia. Retrieved from gbgindonesia:

http://www.gbgindonesia.com/en/manufacturing/article/2016/indonesia_s_fmcg_sector_marre d_by_low_consumer_confidence_but_boosted_by_modern_retail_11456.php

Harianto, Farid \& Sudomo, Siswanto. (1998). Perangkat dan Teknik Analisis Investasi di Pasar Modal Indonesia. Jakarta: Bursa Efek Jakarta.

Husnan, Suad. (2010). Manajemen Keuangan Teori Dan Penerapan (Keputusan Jangka Panjang). Edisi Keempat. BPFE :Yogyakarta.

Ida Ayu Kayika Apsari, N. K. (2019). The Pecking Order Theory Testing on Company Life Cycle . International Research Journal of Management, IT \& Social Sciences, 102.

Iswayuni, Y. \& Suryanto, L. (2002). Analisis Perbedaan Perusahaan Tumbuh dan Tidak Tumbuh dengan Kebijakan Pendanaan, Deviden, Perubahan Harga Saham dan Volume Perdagangan Pada Bursa Efek Jakarta dengan Pendekatan Asosiasi Proksi Investement Opportunity Set (IOS). Jurnal Bisnis dan Ekonomi, Vol.9, No.2, 120-148.

Jiambalvo, J., \& S. Rajgopal. (2002). Institutional ownership and the extent to which stock prices reflect future earnings. Contemporary Accounting Research Vol.19 No.1, 117-145.

Kallapur , S. \& Trombley, M.K. (2001). The Invesment Opportunity Set: Determinants, Consequences and Measurement. Managerial Finance, Vol.27, No.3, 3-15.

Khanna, T., \& K. Palepu. (1999). Policy shocks, market intermediaries, and corporate strategy: the evolution of business groups in Chile and India. Journal of Economics \& Management Strategy. Vol.8 No.2, 271-310.

Klaus Dommes, M. S. (2019). Capital Structures in German Small and Mid Caps: Does Trade-Off or Pecking Order Theory Explain Current Reality Better?. SRP: Journal of Financial Risk Management, 151.

Kole, S. R., \& Lehn, K. M. (1991). Deregulation and the Adaption of Governance Structure: The Case of the US Airline Industry. Journal of Financial Economics, 52.

Lakshmi Balachandra, T. B. (2017). Don't Pitch Like a Girl!: How Gender Stereotypes Influence Investor Decision. Sage Journals: Entrepreneurship Theory and Practice (ETP), 5.

Lisana B. Martinez, V. S. (2018). SMEs capital structure: trade-off or pecking order theory: a systematic review. Emerald: Journal of Small Business and Enterprise Development, 2. 


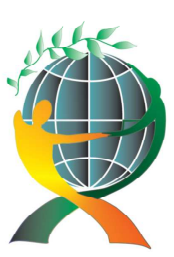

\author{
(online) $=$ ISSN $2285-3642$ \\ ISSN-L = $2285-3642$ \\ Journal of Economic Development, Environment and People \\ Volume 9 , Issue 4, 2020 \\ URL: http://jedep.spiruharet.ro \\ e-mail: office_jedep@spiruharet.ro
}

Malik, D. (2017, Juli Selasa). Viva.co.id \#1 newstainment. Retrieved from Viva.co.id: https://www.viva.co.id/arsip/933987-risiko-investasi-besar-investor-tambang-layak-dapatjaminan

Martin Gunawan. (2017). Pengaruh Faktor Makroekonomi Dan Risiko Terhadap Return Saham Sektor Industri Indonesia. Jurnal Wira Ekonomi Mikroskil, Volume 7, Nomor 02, Oktober 2017.

Myers, S.C. (1984). Capital Structure Puzzle. Journal of Finance, 39 (3), July, 575-592.

Myers, S. C. (1977). Determinants of corporate borrowing. Journal of Financial Economics. Vol.5, 147-175.

Myers, S.C \& N.S Majluf. (1984). Corporate Financing \& Invesment Decision When Firm Have Information That Investor Do Not Have. Journal of Financial Economics, 13, 187-221.

Nur Triani, D. T. (2019). Firm Value: Impact of Investment Decisions, Funding Decisions and Dividend Policies. International Journal of Academic Research in Accounting, Finance and Management Sciences, vol. 9, No. 2, 159.

Nurul Shahnaz Mahdzan, Rozaimah Zainudin \& Nikoo Karimi Shahri. (2016). Interindustry dividend policy determinants in the context of an emerging market. Economic Research-Ekonomska Istraživanja, 29:1, 250-262.

Paul A. Gompers, W. G. (2019). How Do Venture Capitalists Make Decisions? Elsilver: Journal of Financial Economics, 2.

Permata Sari, W. S. (2019). Factors Affecting Investment Opportunity Set: A Study of Company Advantages and Limitations. Sustainable Business Accounting and Management Review, Vol. 1, No. $1,1$.

Rudy Chandra. (2010). Analisis Pemilihan Saham oleh Investor Asing di Bursa Efek Indonesia. Bisnis \& Birokrasi, Jurnal Ilmu Administrasi dan Organisasi, Volume 17, Nomor 2. Mei-Agus 2010, 101113.

Smith, Jr., W. Clifford, \& R. L. Watts. (1992). The investment opportunity set and corporate financing, dividend, and compensation policies. Journal of Financial Economics. Vol.32, 263-292.

Subekti, I., \& Suprapti. (2002). Assosiasi Antara Potensi Pertumbuhan Perusahaan dengan Volume Perdagangan Saham dan Asimetri Informasi. Simposium Nasional Akuntansi V, 356-370.

Sudarma, M., Salim, U., Susanto, H. (1998). Analysis Kausalitas Keputusan Dividen, Investasi dan Pendanaan pada Perusahaan Manufaktur di BES. Wacana Vol 1 No.2.

Umar Farooq, Mian Sajid Nazir, Muhammad Musarrat Nawaz. (2012). Operating or Financial Distress? How much Costly these are? American Journal of Scientific Research, Issue 55, 96-108.

Weston, J. Fred and Brigham, Eugene F., (1994). Dasar-dasar Manajemen Keuangan, edisi 9, Erlangga.

Weston, J. Fred \& Thomas E. Copeland. (1996). Manajemen Keuangan. Jilid 2. Erlangga. Jakarta.

Yusuf Fatoni, Hadi Paramu, Elok Sri Utami. (2013). Determinan Struktur Modal Pada Perusahaan Pertambangan Sub Sektor Batubara Dan Non Batubara Yang Listed Di Bursa Efek Indonesia. Jurnal Bisnis dan Ekonomi (JBE), Vol. 20, No. 1. Maret 2013,1-11. 